\title{
Characterization of High Density Lipoprotein Binding to Human Adipocyte Plasma Membranes
}

\author{
Bessie S. Fong, Pedro O. Rodrigues, Andrew M. Salter, Berwin P. Yip, Jean-Pierre Despres, and Aubie Angel \\ Institute of Medical Science, University of Toronto, and Division of Endocrinology and Metabolism. \\ Department of Medicine, Toronto General Hospital, Toronto, Ontario, Canada M5S 1A8
}

Richard E. Gregg

Molecular Disease Branch, National Heart, Lung and Blood Institute, National Institutes of Health, Bethesda, Maryland 20205

\begin{abstract}
Freshly isolated human adipocytes showed specific uptake of ${ }^{125}$ I-labeled human high density lipoprotein $\left(\mathrm{HDL}_{2}\right.$ and $\mathrm{HDL}_{3}$ ), a portion of which could be released by subsequent incubation with excess unlabeled ligand. To study the mechanism of HDL binding, sucrose gradient-purified adipocyte plasma membranes were incubated with radioiodinated lipoprotein particles under equilibrium conditions in the absence (total binding) or presence (nonspecific binding) of 100-fold excess unlabeled ligand. Specific binding of $\mathrm{HDL}_{2}$ and $\mathrm{HDL}_{3}$, calculated by subtracting nonspecific from total binding, was $\mathrm{Ca}^{++}$independent, unaffected by EDTA, and not abolished by pronase treatment of the membranes. Modification of $\mathrm{HDL}_{3}$ by reductive methylation or cyclohexanedione treatment also failed to affect its binding to adipocyte plasma membranes. High salt concentration (200 $\mathrm{mM} \mathrm{NaCl}$ ) inhibited specific binding of $\mathrm{HDL}_{2}$ and $\mathrm{HDL}_{3}$ but had no effect on LDL binding. A significant portion of ${ }^{125} \mathrm{I}$ $\mathrm{HDL}_{2}$ or ${ }^{125} \mathrm{I}_{-} \mathrm{HDL}_{3}$ binding was consistently inhibited by adding excess unlabeled LDL, but this inhibition was incomplete as compared with a similar molar excess of unlabeled $\mathrm{HDL}_{2}$ or $\mathrm{HDL}_{3}$.

The role of apoproteins (apo) in HDL binding to adipocyte membranes was examined by comparing binding of $\mathrm{HDL}_{2}$ and $\mathrm{HDL}_{3}$ isolated from normal, abetalipoproteinemic (abeta) and apo E-deficient (apo $E_{0}$ ) plasma. Specific binding was observed with all normal and mutant HDL particles. Furthermore, a significant portion (61-78\%) of abeta-HDL $L_{2}$, apo $E_{0}-H_{2} L_{2}$, and apo $\mathrm{E}_{0}-\mathrm{HDL}_{3}$ binding was inhibited by adding 100 -fold excess of unlabeled low density lipoproteins (LDL). The crosscompetition of LDL and HDL binding was confirmed by the ability of normal, abeta, and apo $\mathbf{E}_{0}-\mathrm{HDL}_{2}$ to completely inhibit ${ }^{125} \mathrm{I}-\mathrm{LDL}$ binding. These data suggest that HDL binding is independent of apo $E$ and that the responsible apoprotein(s) of HDL compete with LDL-apo B for binding to the same or closely related site in the adipocyte plasma membrane. Normal and apo $\mathrm{E}_{0}-\mathrm{HDL}_{3}$ binding was also completely inhibited by normal $\mathrm{HDL}_{2}$, which suggested that $\mathrm{HDL}_{2}$ and $\mathrm{HDL}_{3}$ probably
\end{abstract}

Dr. Salter is the recipient of a Canadian Diabetes Association Research Fellowship. Dr. Despres is the recipient of a Fonds de la Recherche en Sante du Quebec postdoctoral fellowship. Address reprint requests to Dr. A. Angel, Room 7368 Medical Sciences Building, Department of Medicine, University of Toronto, Ontario, Canada M5S 1 A8.

Received for publication 21 December 1983 and in revised form 16 January 1985.

J. Clin. Invest.

(C) The American Society for Clinical Investigation, Inc.

0021-9738/85/06/1804/09 \$1.00

Volume 75, June 1985, 1804-1812 bind to the same site. Scatchard analysis of normal $\mathrm{HDL}_{2}$, normal $\mathrm{HDL}_{3}$, and apo $\mathrm{E}_{0}-\mathrm{HDL}_{3}$ binding data best fitted a one-component binding profile with similar equilibrium dissociation constants (40-96 $\mathrm{nM})$. $\mathrm{HDL}_{3}$ binding was found to be effectively inhibited by anti-human apo $\mathrm{AI}$ or anti-human apo AII, but not by anti-human apo $B$ antisera. This binding was also unaffected by monoclonal anti-human apo $B$ or $\mathbf{E}$ antibodies known to inhibit binding of apo $B$ or apo $E$ containing lipoprotein to the LDL receptor of cultured fibroblasts.

These findings, taken together, suggest that human fat cells possess HDL binding sites with apo AI and/or apo AII specificity. The significant but partial inhibition of $\mathrm{HDL}_{2}$ and $\mathrm{HDL}_{3}$ binding by LDL along with the complete inhibition of LDL binding by $\mathrm{HDL}_{2}$ and $\mathrm{HDL}_{3}$ tends to exclude a single binding site that interacts with both lipoproteins and favors the interpretation that LDL and HDL particles bind to multiple recognition sites or to different conformations of the same lipoprotein binding domain on the human fat cell.

\section{Introduction}

Plasma high density lipoproteins (HDL) ${ }^{1}$ are critically important in the metabolism of cellular cholesterol, as these particles are believed to act as efflux acceptors of cholesterol from peripheral tissues for excretion by the liver $(1,2)$ and also deliver cholesterol to steroidogenic tissues for hormone synthesis (38). Variations in plasma HDL concentrations have clinical implications, in that low concentrations of HDL are associated with enhanced risk for premature atherosclerosis, whereas high concentrations indicate some protection against the future development of coronary artery disease $(9,10)$.

The catabolic mechanisms and sites of HDL particle interaction in man remain to be defined. Several reports have shown specific high-affinity binding sites for HDL in steroidogenic tissues of rodents (11-15), especially the adrenal and gonads. Specific binding of human HDL to hepatocytes (1618 ), intestinal mucosal cells (19), as well as cultured human skin fibroblast systems (20) have also been described. While these studies have identified a variety of parenchymal and mesenchymal cells that are capable of interacting with HDL particles, the quantitative importance of each of these tissues in vivo may not be reliably predicted from this information. Additionally, in vitro characteristics of HDL binding to cells in culture may bear little relationship to in vivo circumstances

1. Abbreviations used in this paper: abeta, abetalipoproteinemic; apo, apoprotein; apo AI, apo AII, apo B, apo E, apoproteins AI, AII, B, and $\mathrm{E}$; apo $\mathrm{E}_{0}$, apo E-deficient; $B_{\max }$, maximum binding capacity; $K_{\mathrm{d}}$, equilibrium dissociation constant; KRB, Krebs-Ringer bicarbonate buffer; KRBA, KRB containing 5\% BSA; medium I, $10 \mathrm{mM}$ Tris- $\mathrm{HCl}$ buffer containing $0.25 \mathrm{M}$ sucrose and $1 \mathrm{mM}$ EDTA, $\mathrm{pH}$ 7.4. 
where variations in permeability of vascular endothelium and physiological regulation of receptor activities dictate the balance and distribution of cholesterol from tissue to tissue.

Attempts to quantitate the relative importance of different tissues in the irreversible catabolism of HDL have been made using cumulative markers (21). In the rat, the principal tissue sites of degradation of HDL as monitored by labeled apoprotein (apo) AI are kidney, liver, skin, small intestine, and adipose tissue, in descending order of quantitative significance (21). The sites of HDL catabolism in man are not known, and in vivo assessment using existing methods is not feasible. Alternatively, analysis of tissue biopsy specimens can provide some insight into lipoprotein receptor status and may approximate in vivo characteristics. Several studies have been carried out using human tissue biopsy specimens showing the presence of low density lipoprotein (LDL) and HDL receptors in liver (22) and adipose cells (23).

Human adipose tissue is an important cholesterol storage organ, but does not synthesize significant amounts of cholesterol de novo $(24,25)$. The flux of cholesterol in this tissue is thus mediated by interaction with lipoproteins. In previous studies from this laboratory, high-affinity specific binding of LDL was shown in freshly isolated human adipocytes (23) and purified plasma membranes (26). Specificity was not absolute, in that human $\mathrm{HDL}_{2}$ and $\mathrm{HDL}_{3}$ both competed effectively with the LDL binding site $(23,26)$. This observation implied the presence of binding sites for HDL on adipocytes, and the fact that adipose tissue in man is a large organ (24) indicated that adipose tissue could be an important site of HDL interactions in man despite its quantitative insignificance in the rat (21).

In the present study, we examined in detail the interactions of purified adipocyte plasma membranes from freshly isolated adipocytes with a variety of HDL particles isolated from normal subjects and from patients with genetic apoprotein deficiencies. These studies suggest that interactions of human adipocytes with HDL involve specific binding sites for apo AI and/or apo AII, and are independent of apo E.

\section{Methods}

Lipoprotein isolation, iodination, and chemical modification. Human lipoproteins (LDL d 1.024-1.045; $\mathrm{HDL}_{2}$ d 1.075-1.125; $\mathrm{HDL}_{3}$ d $1.125-1.210)$ were purified from human plasma obtained from the Canadian Red Cross by sequential ultracentrifugation as previously described (27). Apo E-free $\mathrm{HDL}_{2}$ and $\mathrm{HDL}_{3}\left(\right.$ apo $\mathrm{E}_{0}$ ) were isolated from plasma of a patient genetically deficient in apo $\mathrm{E}$ (28). Lipoproteins free of apo B were isolated from plasma of a patient with abetalipoproteinemia (29).

All lipoproteins used in the present study were washed once by ultracentrifugation and dialyzed against $0.15 \mathrm{M} \mathrm{NaCl}$ and $1 \mathrm{mM}$ EDTA, pH 8.6. Lipoproteins were analyzed by agarose gel electrophoresis (Beckman Paragon electrophoresis system) and by SDS polyacrylamide gel electrophoresis (30). Lipoproteins were iodinated by the iodine monochloride method of McFarlane with minor modifications (31).

Reductive methylation of lipoprotein was carried out at $0^{\circ} \mathrm{C}$ using sodium borohydride and aqueous formaldehyde in accordance to Weisgraber et al. (32). Cyclohexanedione treatment was performed by incubating lipoprotein $(0.5 \mathrm{mg} / \mathrm{ml}$ final concentration) in $0.2 \mathrm{M}$ borate buffer, $\mathrm{pH} 8.1$, and $0.15 \mathrm{M}$ cyclohexanedione at $35^{\circ} \mathrm{C}$ for $2 \mathrm{~h}$ as previously described (33).

Isolation of adipocytes and adipocyte plasma membranes. 3-15 g of human properitoneal fat were obtained from patients (aged 37-76) undergoing elective cardiovascular surgery. Human adipocytes were freshly isolated by a modified procedure of Rodbell (34) as previously described (23). Fat tissue was incubated with collagenase $(1.3 \mathrm{mg} / \mathrm{ml})$ in Krebs-Ringer bicarbonate buffer (KRB) containing 5\% bovine serum albumin (BSA) for $1 \mathrm{~h}$ at $37^{\circ} \mathrm{C}$ with constant shaking. Adipocytes were separated from undigested tissue by filtering through a fine nylon mesh and washed thrice with 3 vol of KRB containing $2 \%$ BSA. Approximately $5 \times 10^{5}$ adipocytes were obtained from $1 \mathrm{~g}$ of fat tissue.

Plasma membranes were prepared from the washed, isolated adipocytes by the procedure of McKeel and Jarett (35). Cells were mixed with $8 \mathrm{ml}$ of $10 \mathrm{mM}$ Tris- $\mathrm{HCl}$ buffer containing $0.25 \mathrm{M}$ sucrose and $1 \mathrm{mM}$ EDTA, pH 7.4 (medium I), and broken by 10 up-and-down strokes in a Dounce homogenizer. The crude homogenate was chilled on ice and the congealed fat removed before centrifugation at 16,000 $g$ for $15 \mathrm{~min}$. The pellet was resuspended in medium I and centrifuged at $1000 \mathrm{~g}$ for $10 \mathrm{~min}$. The resultant supernatant was used to prepare plasma membranes and was subjected to centrifugation at $16,000 \mathrm{~g}$ for $20 \mathrm{~min}$. The pellet, resuspended in $1 \mathrm{ml}$ of medium $\mathrm{I}$, was layered onto $11-\mathrm{ml}$ linear sucrose gradient $(32-52 \%$ sucrose in $1 \mathrm{mM}$ EDTA, $10 \mathrm{mM}$ Tris- $\mathrm{HCl}$, $\mathrm{pH} 7.4$ ), and centrifuged at $36,000 \mathrm{rpm}$ for $50 \mathrm{~min}$ in a Beckman SW 40 rotor. The plasma membranes banded near the top of the gradient and were collected, diluted with buffer containing $0.25 \mathrm{M}$ sucrose, $10 \mathrm{mM}$ Tris- $\mathrm{HCl}, \mathrm{pH} 7.4$, and centrifuged at 22,800 $\mathrm{rpm}$ for $30 \mathrm{~min}$ in a Beckman SW 40 rotor. The plasma membrane pellet (referred to as adipocyte membranes) was resuspended in 0.5-1 $\mathrm{ml}$ of $10 \mathrm{mM}$ Tris- $\mathrm{HCl}, \mathrm{pH} 7.4$ and stored at $-20^{\circ} \mathrm{C}$ for later use. The above isolation procedure yielded on the average 101.5 $\pm 9.6-\mu \mathrm{g}$ membrane protein $/ 10^{6}$ cells.

The purity of the plasma membrane fraction was examined by enzyme marker assays. $5^{\prime}$ nucleotidase (36), succinic dehydrogenase (37), acid phosphatase (38), and NADH dehydrogenase (39) were measured as previously described. The purified adipocyte membranes were found to be 3-5-fold higher in $5^{\prime}$ nucleotidase activity compared with cell homogenate, and contained negligible mitochondrial, lysosomal, and microsomal contamination. It was also observed that lipoprotein binding activities of the purified plasma membranes remained unchanged throughout a storage period of $3 \mathrm{mo}$ at $-20^{\circ} \mathrm{C}$.

Lipoprotein uptake and degradation by adipocytes. Freshly isolated adipocytes were incubated with shaking at $37^{\circ} \mathrm{C}$ in $1-0 z$ plastic bottles in $2 \mathrm{ml} \mathrm{KRB}$ buffer containing 5\% BSA (KRBA), $5 \mathrm{mM}$ glucose, ${ }^{125} \mathrm{I}-$ labeled lipoprotein, and $2.5 \mu \mathrm{g} / \mathrm{ml}$ lima bean trypsin inhibitor. Previous studies (23) have indicated that inclusion of trypsin inhibitor in the assay reduces nonspecific degradation of lipoprotein. After $4 \mathrm{~h}$ of incubation, the medium and cells were separated and the cells were washed four times with $3 \mathrm{ml} \mathrm{KRBA}$. The cells were then denatured with $5 \mathrm{ml} 10 \%$ TCA and heated at $80^{\circ} \mathrm{C}$ for $10 \mathrm{~min}$. The TCA precipitate and supernatant were delipidated and the organic extracts were pooled and used for determination of total cell lipid weight. The TCA-insoluble lipid-extracted residues were dried, dissolved in $1 \mathrm{ml}$ of $\mathrm{NaOH}$, and their radioactivity determined. The latter was taken to represent cellular uptake of ${ }^{125}$ I-labeled lipoprotein.

To measure lipoprotein degradation the medium was precipitated with $10 \%$ TCA. The amount of ${ }^{125}$ I-radioactivity in the TCA-soluble fraction was determined after chloroform extraction and represented cell-mediated lipoprotein degradation. Noncell-mediated degradation was measured in flasks containing medium but not cells and the values were subtracted from those with cells.

Lipoprotein binding assay. Binding of ${ }^{125}$ I-labeled lipoproteins to purified adipocyte plasma membranes was assayed by a modified procedure of Basu et al. (40). Standard binding assays were carried out in $75 \mu$ l buffer containing $100 \mathrm{mM} \mathrm{NaCl}, 0.5 \mathrm{mM} \mathrm{CaCl}, 50 \mathrm{mM}$ Tris- $\mathrm{HCl}, \mathrm{pH} 7.5,2 \mathrm{mg} / \mathrm{ml}$ BSA, $10 \mu \mathrm{g}$ purified plasma membrane protein, and varying amounts of ${ }^{125} \mathrm{I}$-labeled lipoprotein. After $1 \mathrm{~h}$ of incubation at $0^{\circ} \mathrm{C}$, the membranes were reisolated by centrifugation in a Beckman airfuge $(100,000 \mathrm{~g})$ or in an Eppendorf centrifuge $(15,600$ g) for $15 \mathrm{~min}$. Both centrifugation procedures pelleted all the membranes that were washed once by centrifugation with $200 \mu \mathrm{l} \mathrm{KRB}$ buffer containing $2 \% \mathrm{BSA}, \mathrm{pH} 7.5$. The bottom of the centrifuge tube containing the pellet was then cut off with a razor blade and the amount of membrane-associated radioactivity was determined in a 
gamma counter. Nonspecific binding was measured by adding 100 fold excess unlabeled ligand. Parallel assays were also set up as no membrane controls with the corresponding amounts of ${ }^{125}$ I-labeled \pm unlabeled ligand, and these values were subtracted from the membrane containing assays.

Apoprotein antibodies. Anti-human apo AI, anti-human apo AII, and anti-human apo B antisera were purchased from Boehringer Mannheim Biochemicals, Indianapolis, IN. Monoclonal antibodies directed against apo E (1D7) and apo B (3A10) were kindly provided by Dr. R. Milne and Dr. Y. Marcel of the Clinical Research Institute of Montreal, Quebec H2W 1R7, Canada.

Binding data analysis. Binding data were analyzed by the method of Scatchard (41) and were fitted by an iterative nonlinear least square procedure (42) on a MEDAC S-100 Z80 microcomputer (kindly provided by Dr. D. Isenman, Department of Biochemistry, University of Toronto).

\section{Results}

The apoprotein compositions of the various human $\mathrm{HDL}_{2}$ (d 1.075-1.125) and $\mathrm{HDL}_{3}(\mathrm{~d} 1.12-1.210)$ used in the present study were analyzed by SDS-polyacrylamide gel electrophoresis and the results are shown in Fig. 1. Apo E was present in $\mathrm{HDL}_{2}$ isolated from plasma of normal individuals but was clearly missing in the $\mathrm{HDL}_{2}$ isolated from the apo E-deficient (apo $\mathrm{E}_{0}$ ) patient. The apoproteins of $\mathrm{HDL}_{3}$ from both the normal and apo $\mathrm{E}_{0}$ individuals showed similar polyacrylamide gel patterns, indicating the absence of apo $\mathrm{E}$ in our normal $\mathrm{HDL}_{3}$ ultracentrifugal preparations.

The interaction of normal ${ }^{125} \mathrm{I}-\mathrm{HDL}_{2}$ and ${ }^{125} \mathrm{I}-\mathrm{HDL}_{3}$ by adipocytes isolated from human fat tissue was assayed after 4 h of incubation with $10 \mu \mathrm{g} / \mathrm{ml}{ }^{125} \mathrm{I}$-labeled $\mathrm{HDL}$ at $37^{\circ} \mathrm{C}$. Table I shows that ${ }^{125} \mathrm{I}-\mathrm{HDL}_{2}$ and ${ }^{125} \mathrm{I}_{-}-\mathrm{HDL}_{3}$ radioactivity was found to be associated with the cells (uptake). About $90 \%$ of this cellular uptake of ${ }^{125}$ I-labeled HDL was specifically inhibited by the addition of 25 -fold excess unlabeled HDL in the incubation medium. Results in Table I also show that in three out of the four experiments, TCA-soluble degradation products (small peptides) of ${ }^{125} \mathrm{I}-\mathrm{HDL}_{2}$ and ${ }^{125} \mathrm{I}-\mathrm{HDL}_{3}$ could be detected in the incubation medium, but this degradation did not appear to be inhibited when excess unlabeled HDL was added (experiments 2 and 3 ).

A portion of the ${ }^{125} \mathrm{I}_{-}-\mathrm{HDL}_{2}$ and ${ }^{125} \mathrm{I}-\mathrm{HDL}_{3}$ uptake by adipocytes was observed to be reversibly dissociated. In these

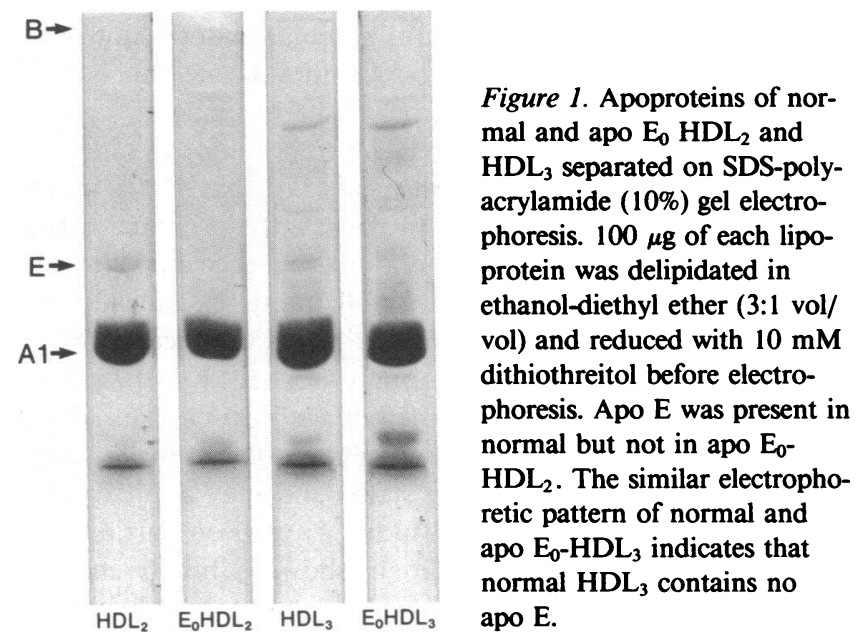

experiments, cells were reisolated and washed with KRBA after $4 \mathrm{~h}$ of incubation with ${ }^{125} \mathrm{I}$-labeled $\mathrm{HDL}$ and were then resuspended in fresh KRBA. After incubation for 30-120 min at $37^{\circ} \mathrm{C}$ with constant shaking, the amount of ${ }^{125}$ I-radioactivity that remained associated with the cells was measured. Results in Fig. 2 show that the cell-associated ${ }^{125} \mathrm{I}_{-} \mathrm{HDL}_{2}$ and ${ }^{125} \mathrm{I}$ $\mathrm{HDL}_{3}$ radioactivity decreased with time. This decrease appeared to level off between 1 and $2 \mathrm{~h}$ after addition of unlabeled ligand and $59-61 \%$ of the ${ }^{125} \mathrm{I}-\mathrm{HDL}$ radioactivity remained associated with the cells. The dissociated radioactivity (measured in the incubation medium) was all TCA-precipitable and could represent $\mathrm{HDL}$ particles that were reversibly bound to the surface of the adipocytes.

The binding characteristics of HDL particles to human adipocytes were more specifically examined by employing plasma membranes purified from the freshly isolated adipocytes. Fig. 3 shows a time course of ${ }^{125} \mathrm{I}-\mathrm{HDL}_{2}$ binding to adipocyte plasma membranes at $0^{\circ} \mathrm{C}$. Total and nonspecific binding, measured respectively in the absence and presence of 100 -fold excess unlabeled $\mathrm{HDL}_{2}$, reached equilibrium after $60 \mathrm{~min}$ of incubation. Similar results were obtained for ${ }^{125} \mathrm{I}-\mathrm{HDL}_{3}$ binding (data not shown). All subsequent experiments on $\mathrm{HDL}_{2}$ and $\mathrm{HDL}_{3}$ binding were thus carried out at $0^{\circ} \mathrm{C}$ for $1 \mathrm{~h}$.

Human adipocyte membranes were previously shown to specifically bind LDL, and this binding was completely inhibited

Table I. Uptake and Degradation of ${ }^{125} \mathrm{I}-\mathrm{HDL} \mathrm{L}_{2}$ and ${ }^{125} \mathrm{I}-\mathrm{HDL} \mathrm{L}_{3}$ by Freshly Isolated Human Adipocytes

\begin{tabular}{|c|c|c|c|c|c|c|}
\hline \multirow{2}{*}{ Experiment } & \multirow{2}{*}{ Cell } & \multirow{2}{*}{${ }^{125} \mathrm{I}-\mathrm{HDL}$} & \multicolumn{4}{|c|}{$\mu \mathrm{g}$ HDL protein/g cell lipid/4 h } \\
\hline & & & \multicolumn{2}{|l|}{ Uptake } & \multicolumn{2}{|l|}{ Degradation } \\
\hline 1 & F $70 \mathrm{yr}$ & $\mathrm{HDL}_{2}$ & $0.45 \pm 0.07$ & $0.04 \pm 0.002$ & 0 & 0 \\
\hline 2 & M $66 \mathrm{yr}$ & $\mathrm{HDL}_{2}$ & $0.84 \pm 0.20$ & $0.06 \pm 0.01$ & $0.12 \pm 0.04$ & $0.08 \pm 0.05$ \\
\hline 3 & M $46 \mathrm{yr}$ & $\mathrm{HDL}_{3}$ & $2.29 \pm 0.23$ & $0.21 \pm 0.04$ & $0.20 \pm 0.02$ & $0.17 \pm 0.06$ \\
\hline 4 & M $53 \mathrm{yr}$ & $\mathrm{HDL}_{3}$ & $1.23 \pm 0.12$ & $0.17 \pm 0.004$ & $0.25 \pm 0.04$ & $0.04 \pm 0.02$ \\
\hline
\end{tabular}

Adipocytes were obtained by collagenase digestion of properitoneal fat obtained from four different individuals. The freshly isolated adipocytes were incubated with $10 \mu \mathrm{g} / \mathrm{ml}^{125} \mathrm{I}_{-\mathrm{HDL}_{2}}$ or ${ }^{125} \mathrm{I}-\mathrm{HDL}_{3}$ for $4 \mathrm{~h}$ at $37^{\circ} \mathrm{C}$ with constant shaking. Parallel flasks were set up containing excess unlabeled $\mathrm{HDL}_{2}$ or $\mathrm{HDL}_{3}(250 \mu \mathrm{g} / \mathrm{ml})$. The amounts of TCA-precipitable radioactivity associated with the cells (uptake) and TCA-soluble radioactivity in the incubation medium (degradation) were determined as described in Methods. Each value represents the mean \pm 1 SD of triplicate assays. 


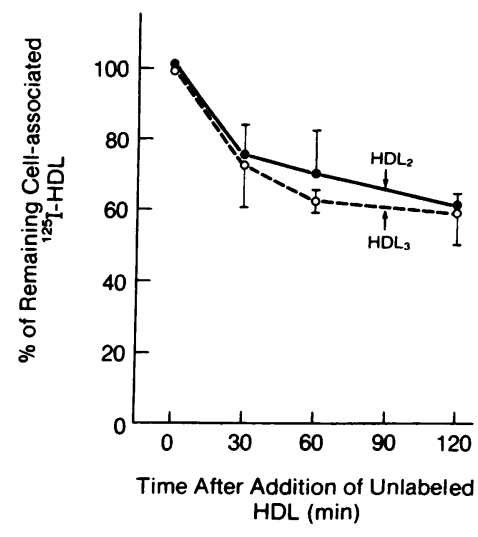

containing $250 \mu \mathrm{g} / \mathrm{ml}$ of the corresponding unlabeled ligand. After further incubation for $30-120 \mathrm{~min}$ at $37^{\circ} \mathrm{C}$, aliquots of the cells were reisolated and the amount of TCA-precitable radioactivity that remained associated with the cells was determined. Each point represents the mean \pm 1 SD of triplicate assays.

by $\mathrm{HDL}_{2}$ and $\mathrm{HDL}_{3}(26)$. The effect of $\mathrm{LDL}$ on $\mathrm{HDL}_{2}$ and $\mathrm{HDL}_{3}$ binding was therefore examined. Fig. $4, A$ and $B$ show that excess unlabeled LDL inhibited ${ }^{125} \mathrm{I}_{-} \mathrm{HDL}_{2}$ and ${ }^{125} \mathrm{I}_{-}-\mathrm{HDL}_{3}$ binding, but not to the same extent as as unlabeled $\mathrm{HDL}_{2}$ or $\mathrm{HDL}_{3}$ at similar molar excess. The results show that $\sim 75 \%$ of $\mathrm{HDL}_{2}$ (Fig. $4 \mathrm{~A}$ ) and $65 \%$ of $\mathrm{HDL}_{3}$ (Fig. $4 \mathrm{~B}$ ) binding was inhibited by 25 -fold molar excess of unlabeled LDL as compared with $85-95 \%$ inhibition obtained in the presence of 25 fold molar excess of the homologous ligand. Inhibition of ${ }^{125} \mathrm{I}-$ $\mathrm{HDL}_{2}$ and ${ }^{125} \mathrm{I}_{-} \mathrm{HDL}_{3}$ binding appeared to level off between 50- and 100-fold molar excess of unlabeled lipoproteins. At 100-fold molar excess of LDL, $85 \%$ of $\mathrm{HDL}_{2}$ (Fig. $4 \mathrm{~A}$ ) and $80 \%$ of $\mathrm{HDL}_{3}$ (Fig. $4 \mathrm{~B}$ ) binding was inhibited. Thus, LDL inhibited $\mathrm{HDL}_{2}$ and $\mathrm{HDL}_{3}$ binding significantly but incompletely.

The specific binding of $\mathrm{HDL}_{2}$ and $\mathrm{HDL}_{3}$ to adipocyte plasma membranes was unaffected when EDTA was added to the binding buffer at a final concentration of $10 \mathrm{mM}$ or when calcium was omitted (Table II). The effect of pronase treatment on HDL binding was also examined. In three separate experiments, preincubation of adipocyte membranes with pronase (30 $\mu \mathrm{g} / \mathrm{ml}$ ) failed to abolish ${ }^{125} \mathrm{I}_{-} \mathrm{HDL}_{2}$ specific binding $(2.68 \pm 1.24 \mu \mathrm{g} / \mathrm{mg}$ for control vs. $3.23 \pm 1.19 \mu \mathrm{g} / \mathrm{mg}$ for pronasetreated membranes). Similar characteristics have been observed for LDL binding to adipocyte membranes (26). High salt, however, affected LDL and HDL binding differently. Table III shows that $\mathrm{HDL}_{2}$ and $\mathrm{HDL}_{3}$ specific binding was reduced

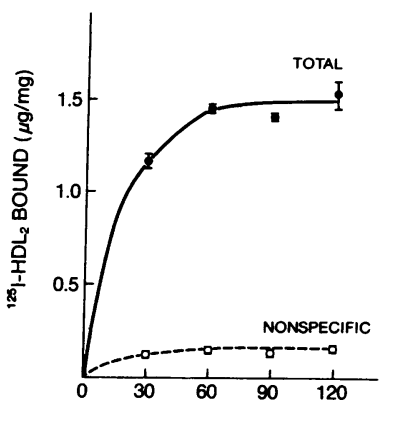

Figure 3. Time course of ${ }^{125} \mathrm{I}$ $\mathrm{HDL}_{2}$ binding to human adipocyte plasma membranes. Adipocytes were isolated from properitoneal fat of a 61-yr-old female by collagenase digestion for adipocyte plasma membrane purification. 10 $\mu \mathrm{g}$ (protein) of purified plasma membranes were incubated at $0^{\circ} \mathrm{C}$ with $20 \mu \mathrm{g} / \mathrm{ml}^{125} \mathrm{I}-\mathrm{HDL}_{2}$ in the absence $(\bullet)$ or presence of 100 fold excess unlabeled $\mathrm{HDL}_{2}(\mathrm{O})$ for 30-120 min. Each point represents the average and range of duplicate assays.

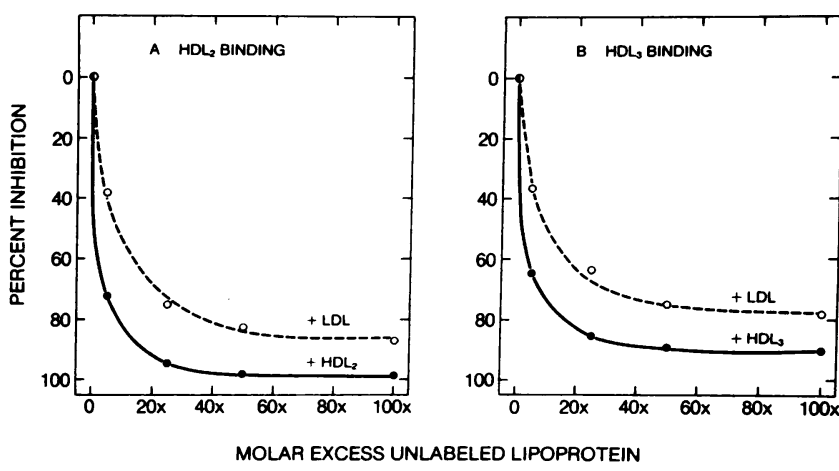

Figure 4. Effect of $\mathrm{LDL}$ on ${ }^{125} \mathrm{I}-\mathrm{HDL}_{2}(A)$ and ${ }^{125} \mathrm{I}_{-} \mathrm{HDL}_{3}(B)$ binding to human adipocyte plasma membranes. Adipocyte plasma membranes were purified from properitoneal fat of two different male patients, aged $59(A)$ and $63(B)$, respectively. $10 \mu \mathrm{g}$ (protein) of the purified membranes was incubated with $2.5 \mu \mathrm{g} / \mathrm{ml}^{125} \mathrm{I}-\mathrm{HDL}_{2}$ or ${ }^{125} \mathrm{I}$ $\mathrm{HDL}_{3}$ in the absence $(0)$ or presence $(0, \bullet)$ of varying amount of unlabeled lipoprotein for $1 \mathrm{~h}$ at $0^{\circ} \mathrm{C}$. LDL did not inhibit ${ }^{125} \mathrm{I}-\mathrm{HDL}_{2}$ or ${ }^{125} \mathrm{I}_{-} \mathrm{HDL}_{3}$ binding to the same extent as unlabeled $\mathrm{HDL}_{2}$ or $\mathrm{HDL}_{3}$ in equivalent molar excess.

$\sim 40 \%$ in the presence of $200 \mathrm{mM} \mathrm{NaCl}$ as compared with $100 \mathrm{mM} \mathrm{NaCl}$ (standard condition used in our binding assay), while LDL specific binding was unaffected by high $\mathrm{NaCl}$ concentration as previously reported (26). Chemical modification of lysine (reductive methylation) or arginine (cyclohexanedione treatment) residues of $\mathrm{HDL}_{3}$ had no effect on its binding to adipocyte membranes. In four experiments, specific binding of reductively methylated $\mathrm{HDL}_{3}(2.88 \pm 0.94 \mu \mathrm{g} / \mathrm{mg}$, mean $\pm \mathrm{SD})$ and cyclohexanedione-treated $\mathrm{HDL}_{3}(2.91 \pm 1.1 \mu \mathrm{g} /$ $\mathrm{mg}$ ) were not significantly different from native unmodified $\mathrm{HDL}_{3}(2.99 \pm 0.93 \mu \mathrm{g} / \mathrm{mg})$.

The possible role of apo $\mathrm{E}$ in the recognition of lipoproteins by human adipocyte membranes was investigated using apo E-free $\mathrm{HDL}_{2}$ and apo E-free $\mathrm{HDL}_{3}$ fractions isolated from the plasma of a patient genetically deficient in apo $\mathrm{E}$ (apo $\mathrm{E}_{0}$; Fig. 1). The results in Table IV show that $>90 \%$ of normal ${ }^{125} \mathrm{I}$ $\mathrm{HDL}_{3}$ binding was inhibited by excess normal $\mathrm{HDL}_{2}$ or $\mathrm{HDL}_{3}$

Table II. Effect of EDTA and Calcium on $H D L_{2}$ and $H D L_{3}$ Specific Binding

\begin{tabular}{|c|c|c|}
\hline & \multicolumn{2}{|c|}{ Specific binding ( $\mu \mathrm{g}$ HDL protein/mg membrane protein) } \\
\hline & $\mathrm{HDL}_{2}$ & $\mathrm{HDL}_{3}$ \\
\hline Standard & $3.90 \pm 0.20^{*}(100 \%) \ddagger$ & $2.14 \pm 0.01(100 \%)$ \\
\hline +EDTA & $3.85 \pm 0.15 \quad(99 \%)$ & $2.33 \pm 0.03(109 \%)$ \\
\hline Minus $\mathrm{Ca}^{++}$ & $4.35 \pm 0.04 \quad(112 \%)$ & $2.31 \pm 0.06(108 \%)$ \\
\hline
\end{tabular}

Adipocyte plasma membranes were purified from properitoneal fat of a 59-yr-old male. Binding assays were carried out using $10 \mu \mathrm{g}$ (protein) of purified membranes and $40 \mu \mathrm{g} / \mathrm{ml}^{125} \mathrm{I}-\mathrm{HDL}_{2}$ or ${ }^{125} \mathrm{I}-\mathrm{HDL}_{3}$ in standard binding buffer containing $50 \mathrm{mM}$ Tris- $\mathrm{HCl}, 100 \mathrm{mM} \mathrm{NaCl}$, $0.5 \mathrm{mM} \mathrm{CaCl}_{2}$, and $2 \mathrm{mg} / \mathrm{ml} \mathrm{BSA}, \mathrm{pH} 7.5$. In parallel assays, calcium was omitted or $10 \mathrm{mM}$ EDTA (final concentration) was added. Specific binding was determined as the difference in binding between that in the presence and that in the absence of 100 -fold excess unlabeled ligand. Experiment was repeated with two other membrane preparations and similar results were obtained.

* Average \pm range of duplicate assays.

$\ddagger$ As a percentage of standard condition binding. 
Table III. Effect of $\mathrm{NaCl}$ on $\mathrm{HDL}_{2}$, $H D L_{3}$, and $L D L$ Specific Binding

\begin{tabular}{|c|c|c|}
\hline & \multicolumn{2}{|c|}{ Specific binding $(\mu g / m g)$} \\
\hline & \multicolumn{2}{|c|}{$\mathrm{NaCl}$ concentration $(m M)$} \\
\hline & 100 & 200 \\
\hline $\mathrm{HDL}_{2}(n=2)$ & $4.82 \pm 0.92^{*}$ & $2.99 \pm 0.52 \quad(62 \%) \S$ \\
\hline $\mathrm{HDL}_{3}(n=7)$ & $2.66 \pm 0.90 \ddagger$ & $1.53 \pm 0.49^{\| \prime}(57 \%)$ \\
\hline $\operatorname{LDL}(n=4)$ & $1.88 \pm 1.82 \ddagger$ & $1.86 \pm 1.55 \pi(97 \%)$ \\
\hline
\end{tabular}

Adipocyte plasma membranes were purified from human properitoneal fat as described in Methods. Binding assays were carried out using $10 \mu \mathrm{g}$ (protein) of purified membranes and $40 \mu \mathrm{g} / \mathrm{ml}{ }^{125} \mathrm{I}$-labeled lipoprotein in binding buffer containing $50 \mathrm{mM}$ Tris- $\mathrm{HCl}(\mathrm{pH} \mathrm{7.5)}$, $0.5 . \mathrm{mM} \mathrm{CaCl}_{2}, 2 \mathrm{mg} / \mathrm{ml} \mathrm{BSA}$, and $100 \mathrm{mM}$ (standard) or $200 \mathrm{mM}$ $\mathrm{NaCl}$. Specific binding was determined as the difference in binding between that in the presence and that in the absence of 100 -fold excess unlabeled ligand. $n$, number of different membrane preparations. * Average \pm range.

$\ddagger$ Mean \pm SD.

$\S$ Binding as a percentage of $100 \mathrm{mM} \mathrm{NaCl}$.

"Significantly different from $100 \mathrm{mM} \mathrm{NaCl}, P<0.01$ by paired $t$ test.

I Not significantly different from $100 \mathrm{mM} \mathrm{NaCl}$.

and that excess apo $\mathrm{E}_{0}-\mathrm{HDL}_{3}$ was as effective as normal $\mathrm{HDL}$ in inhibiting ${ }^{125} \mathrm{I}_{-} \mathrm{HDL}_{3}$ binding. Only $58 \%$ of the ${ }^{125} \mathrm{I}_{-} \mathrm{HDL}_{3}$ binding was inhibited by 100 -fold (protein) excess unlabeled LDL. In exp. 2, ${ }^{125} \mathrm{I}$-apo $\mathrm{E}_{0}-\mathrm{HDL}_{3}$ bound specifically to adipocyte plasma membranes, and this binding was also inhibited completely by normal $\mathrm{HDL}_{2}$, normal $\mathrm{HDL}_{3}$, and abeta $\mathrm{HDL}_{3}$. Again excess LDL only partially inhibited apo $\mathrm{E}_{0}-\mathrm{HDL}$ binding. These findings indicate that binding of HDL to fat cell membranes is independent of apo E. Table IV also shows the results of a cross-inhibition study on the effect of various normal and mutant HDL particles on LDL binding to adipocyte membranes. In exp. 3, ${ }^{125}$ I-LDL binding was found to be completely inhibited by 100 -fold excess unlabeled normal $\mathrm{HDL}_{2}$, normal $\mathrm{HDL}_{3}$, abeta $\mathrm{HDL}_{3}$, apo $\mathrm{E}_{0}-\mathrm{HDL}_{2}$, and apo $\mathrm{E}_{0}-\mathrm{HDL}_{3}$.

The specific binding of various ${ }^{125}$ I-labeled $\mathrm{HDL}_{2}$ and
$\mathrm{HDL}_{3}$ particles to a number of different human adipocyte plasma membrane preparations are listed in Table V. Binding assays were carried out using $40 \mu \mathrm{g} / \mathrm{ml}{ }^{125} \mathrm{I}$-labeled ligand. Partial inhibition of normal, abeta, and apo $\mathrm{E}_{0} \mathrm{HDL}_{2}$ or $\mathrm{HDL}_{3}$ specific binding was observed in the presence of 100 -fold protein excess unlabeled LDL in all cases.

The possibility that apo AI and/or apo AII are primarily involved in the binding of $\mathrm{HDL}_{2}$ and $\mathrm{HDL}_{3}$ to adipocyte membranes was tested by using monoclonal and polyclonal antibodies to specific apoproteins. Fig. 5 shows that $\mathrm{HDL}_{3}$ binding was inhibited by anti-human apo $\mathrm{AI}$ and anti-human apo AII, but not by anti-human apo B antibodies. Furthermore, two monoclonal antibodies directed against apo E (1D7) and apo B (3A10) that have been shown to inhibit apo E-HDL and LDL binding, respectively, to human fibroblasts $(43,44)$, also failed to have any effect on $\mathrm{HDL}_{3}$ binding to adipocyte membrane. Similar inhibition by anti-apo AI and anti-apo AII was observed for $\mathrm{HDL}_{2}$ binding (data not shown).

The affinity of $\mathrm{HDL}_{2}$ and $\mathrm{HDL}_{3}$ binding to human adipocyte membranes was examined by dose-response binding assays. Fig. $6 \mathrm{~A}$ shows that total binding of ${ }^{125} \mathrm{I}_{-} \mathrm{HDL}_{2}$ was ligand concentration dependent and was saturable at $\sim 40 \mu \mathrm{g} /$ $\mathrm{ml}{ }^{125} \mathrm{I}-\mathrm{HDL}_{2}$. Nonspecific binding, measured in the presence of 100 -fold excess unlabeled $\mathrm{HDL}_{2}$, also appeared to be curvilinear and saturable and represented $<10 \%$ of total binding. Specific binding was obtained by subtracting nonspecific binding from total. The addition of 100 -fold protein (25-fold molar) excess of unlabeled LDL reduced total ${ }^{125} \mathrm{I}_{-} \mathrm{HDL}_{2}$ binding by $\sim 50 \%$. The Scatchard plot for ${ }^{125} \mathrm{I}_{-} \mathrm{HDL}_{2}$ specific binding (Fig. $6 \mathrm{~B}$ ) best fitted a one-component system. Dose-response binding assays were also carried out with normal $\mathrm{HDL}_{3}$ (Fig. $7 A$ and $B)$ and with apo $\mathrm{E}_{0}-\mathrm{HDL}_{3}$, with similar results.

The equilibrium dissociation constant $\left(K_{d}\right)$ and maximum binding capacity $\left(B_{\max }\right)$ obtained for normal $\mathrm{HDL}_{2}$, normal $\mathrm{HDL}_{3}$, and apo $\mathrm{E}_{0}-\mathrm{HDL}_{3}$ by Scatchard analysis are listed in Table VI. With the exception of exp. 2, the binding affinities and capacities for various HDL particles were remarkably similar.

\section{Discussion}

The present study extends our previous work on LDL interaction with adipocytes $(23,26)$ and demonstrates that human

Table IV. Effect of Various Lipoproteins on Normal $H D L_{3}$, Apo E-deficient $H D L_{3}$, and Normal LDL Binding to Human Adipocyte Plasma Membranes

\begin{tabular}{|c|c|c|c|c|c|c|c|c|c|}
\hline \multirow[b]{3}{*}{ Experiment } & \multirow[b]{3}{*}{ Membrane } & \multirow[b]{3}{*}{${ }^{125}$ I-Lipoprotein } & \multirow[b]{3}{*}{ Control } & \multicolumn{6}{|c|}{$\mu \mathrm{g}$ Lipoprotein bound/mg membrane protein } \\
\hline & & & & \multicolumn{6}{|c|}{ + Excess unlabeled lipoproteins } \\
\hline & & & & $\mathrm{HDL}_{2}$ & $\mathrm{HDL}_{3}$ & $\mathrm{E}_{0}-\mathrm{HDL}_{2}$ & $E_{0}-\mathrm{HDL}_{3}$ & Abeta-HDL $\mathrm{H}_{3}$ & LDL \\
\hline 1 & M 50 yr & $\mathrm{HDL}_{3}$ & 2.50 & 0.23 & 0.23 & ND & 0.18 & ND & 1.04 \\
\hline 2 & M 53 yr & $\mathrm{E}_{0}-\mathrm{HDL}_{3}$ & 2.42 & 0.21 & 0.17 & ND & 0.15 & 0.21 & 0.94 \\
\hline 3 & M 50 yr & LDL & 1.46 & 0.10 & 0.07 & 0.06 & 0.05 & 0 & 0.15 \\
\hline
\end{tabular}

Adipocyte plasma membranes were obtained from properitoneal fat tissues as described in Methods. $10 \mu \mathrm{g}$ (protein) adipocyte membranes were incubated with $40 \mu \mathrm{g} / \mathrm{ml}{ }^{125}$ I-labeled lipoprotein (control). Parallel assays contained, in addition, 100 -fold protein excess of the indicated unlabeled lipoprotein. Each value represents the average of duplicate assays. Normal and apo $E_{0}{ }^{125}$ - $-\mathrm{HDL}_{3}$ bound specifically to adipocyte membranes. Both bindings were partially inhibited by unlabeled LDL but were completely inhibited by $\mathrm{HDL}_{2}$ and by each other. These results suggest that $\mathrm{HDL}_{2}$ and $\mathrm{HDL}_{3}$ probably bind to the same site and that apo $\mathrm{E}$ is not required for binding. The various unlabeled HDL particles also completely inhibited ${ }^{125}$ I-LDL binding. 
Table V. Specific Binding of Different $H D L$ Particles to Human Adipocyte Plasma Membranes

\begin{tabular}{lll}
\hline & \multicolumn{2}{l}{ Specific binding } \\
\cline { 2 - 3 } & $\mu \mathrm{g}$ HDL/mg membrane & \% Inhibited by LDL \\
\hline Normal $\mathrm{HDL}_{2}(n=11)$ & $3.50 \pm 1.21^{*}$ & $61.5 \pm 10.6$ \\
Normal $\mathrm{HDL}_{3}(n=4)$ & $1.95 \pm 0.72$ & $57.6 \pm 8.8$ \\
Abeta $\mathrm{HDL}_{2}(n=3)$ & $2.76 \pm 1.05$ & $78.0 \pm 5.2$ \\
Apo $\mathrm{E}_{0} \mathrm{HDL}_{2}(n=3)$ & $3.83 \pm 1.16$ & $74.0 \pm 1.7$ \\
Apo $\mathrm{E}_{0} \mathrm{HDL}_{3}(n=7)$ & $2.78 \pm 1.21$ & $61.3 \pm 8.3$
\end{tabular}

Specific binding of the various normal and mutant HDL particles was measured at $40 \mu \mathrm{g} / \mathrm{ml}^{125} \mathrm{I}$-labeled ligand and $10 \mu \mathrm{g}$ (protein) purified adipocyte plasma membranes as described in Methods. The portion of HDL binding inhibited by LDL was assayed in the presence of 100 -fold protein excess unlabeled LDL. Human adipocyte plasma membranes displayed similar specific binding of normal, abeta, or apo $E_{0}$ HDL particles and all were partially inhibited by LDL.

* Mean \pm SD

fat cells interact with a variety of normal and mutant HDL particles in a specific manner. These findings are consistent with recent studies showing in vivo catabolism of HDL apoprotein in fat tissue (21), and emphasize the possibility that fat tissue in man, because of its mass, may be quantitatively more important compared with lower animals. The observed degradation of HDL by the freshly isolated human adipocyte system was, however, variable. While HDL degradation was apparently cell dependent, its relation to cellular internalization and processing remains to be elucidated. Our studies on HDL interaction with freshly isolated human adipocytes demonstrated that a significant portion of the HDL taken up by the fat cells was reversibly dissociated. While the latter probably represents surface-bound HDL particles, the undissociable portion probably represents internalized or otherwise sequestered particles. Furthermore, because cellular processing (presumably internalization and degradation) of HDL could occur simulta-

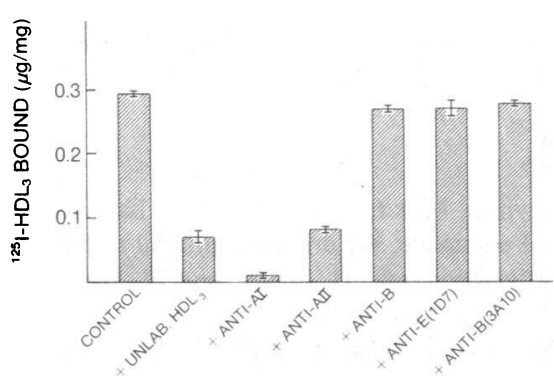

Figure 5. Effect of various anti-apoprotein antibodies on ${ }^{125} \mathrm{I}_{-} \mathrm{HDL}_{3}$ binding to human adipocyte membranes. Adipocyte plasma membranes were purified from properitoneal fat of a 55-yr-old male as described in Methods. ${ }^{125} \mathrm{I}_{-} \mathrm{HDL}_{3}$ binding was carried out by incubating $10 \mu \mathrm{g}$ (protein) of the purified membranes with $0.27 \mu \mathrm{g} / \mathrm{ml}$ at $0^{\circ} \mathrm{C}$ (control). Parallel assays contained unlabeled $\mathrm{HDL}_{3}$ (100-fold excess) or different anti-apoprotein antibodies as indicated. Anti-AI, anti-AII, and anti-B were sheep anti-human apoprotein antisera obtained from Boehringer Mannheim Biochemicals. 1D7 and 3A10 were monoclonal antibodies directed against apo-E and apo-B, respectively.
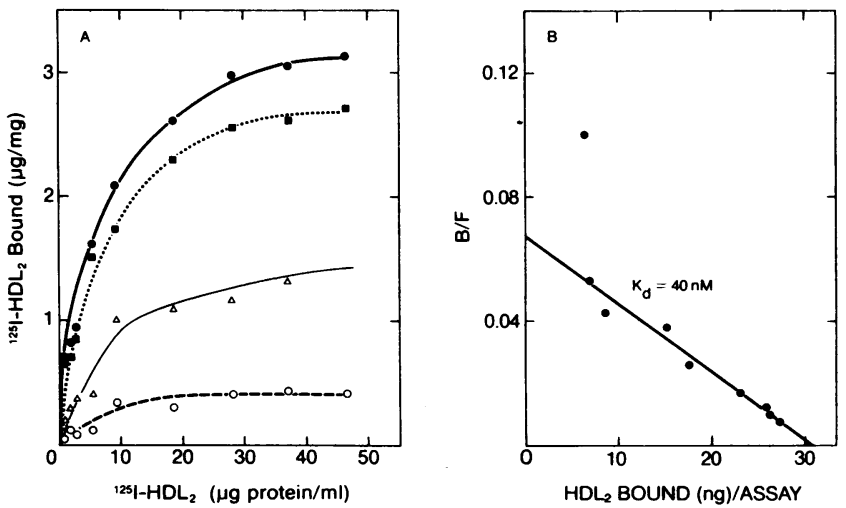

Figure 6. ${ }^{125} \mathrm{I}-\mathrm{HDL}_{2}$ binding to human adipocyte plasma membranes. Adipocytes were isolated from properitoneal fat of a 67-yr-old male by collagenase digestion and adipocyte plasma membrane were purified. $(A)$ Purified plasma membranes ( $10 \mu \mathrm{g}$ protein) were incubated with varying concentrations of ${ }^{125} \mathrm{I}-\mathrm{HDL}_{2}$ in the absence $(\bullet)$ or presence of 100-fold excess unlabeled $\mathrm{HDL}_{2}(0)$ or in the presence of 100 -fold protein excess unlabeled LDL $(\Delta)$. Specific binding $(\square)$ was calculated by subtracting nonspecific ( $(0)$ from total binding $(\bullet)$ and was saturable. Excess unlabeled LDL partially inhibited ${ }^{125} \mathrm{I}_{-} \mathrm{HDL}_{2}$ specific binding. Each point represents the average of duplicate assays. (B) Scatchard plot of ${ }^{125} \mathrm{I}-\mathrm{HDL}_{2}$ specific binding. $\mathrm{B} / \mathrm{F}$ represents the amount of specifically bound ${ }^{125} \mathrm{HDL}_{2}$ (nanograms protein) divided by the amount of unbound (nanograms protein) in the assay. Abscissa shows the amount of ${ }^{125}{ }^{-}-\mathrm{HDL}_{2}$ specifically bound (nanograms protein) to the membranes per assay. The data were best fitted to a straight line by computer analysis. The intercept of the line at the $\mathrm{x}$ axis represents maximum binding. The $K_{\mathrm{d}}$ equals $-1 /$ slope of the plot and measures the affinity of the $\mathrm{HDL}_{2}$ binding. To convert from nanograms of $\mathrm{HDL}_{2}$ protein to moles, the molecular weight of $3.6 \times 10^{5}$ (40\% protein) was used in the calculation.

neously, the accurate definition of binding in intact cells is difficult. Thus, in order to characterize binding of HDL to adipocytes independent of cellular processing, we resorted to the use of purified plasma membranes.

The results of the membrane studies demonstrated that ${ }^{125} \mathrm{I}-\mathrm{HDL}_{2}$ and ${ }^{125} \mathrm{I}-\mathrm{HDL}_{3}$ were bound to purified adipocyte membranes in a specific and saturable manner. This binding was insensitive to EDTA, independent of calcium (Table II), and not inhibited by pronase, thus resembling HDL binding in a number of ex vivo tissue studies $(13,45)$ including human liver membranes (46). In addition, $\mathrm{HDL}_{2}$ and $\mathrm{HDL}_{3}$ inhibited each other's binding to human adipocyte membranes, showed similar $K_{d}$ (Table VI), and were inhibited by high salt (Table III). These similar binding characteristics suggest that $\mathrm{HDL}_{2}$ and $\mathrm{HDL}_{3}$ particles bind to the same site in human adipocyte membranes.

The nonspecific binding of ${ }^{125}$ I-labeled HDL to adipocyte plasma membranes accounts for only $5-10 \%$ of total HDL binding and appeared to have a saturable profile (Figs. 6 and 7). This is consistent with the curvilinear nonspecific LDL binding previously observed (26). A saturable nonspecific binding curve may be due in part to the constant ratio of unlabeled to ${ }^{125}$ I-labeled ligand $(100: 1)$ in the assay for all ligand concentrations used. This explanation is inadequate, however, as total binding was also saturable. The highly vesiculated nature of the adipose cell surface as frequently observed in electron microscopic studies (47) could have 

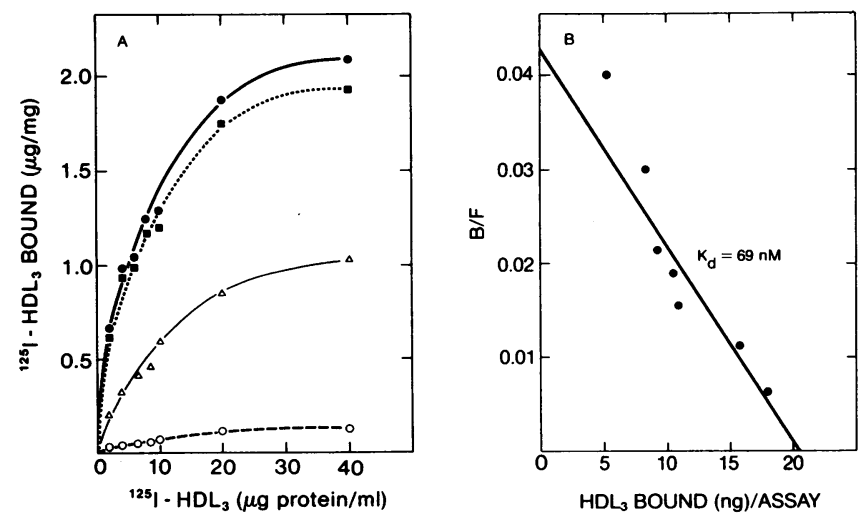

Figure 7. ${ }^{125} \mathrm{I}_{-} \mathrm{HDL}_{3}$ binding to human adipocyte plasma membranes. Plasma membranes were purified from adipocytes that were isolated from properitoneal fat obtained from a 61-yr-old male. $(A)$ Purified plasma membranes ( $9.6 \mu \mathrm{g}$ protein) were incubated with varying concentrations of ${ }^{125} \mathrm{I}-\mathrm{HDL}_{3}$ in the absence $(\bullet)$ or presence of 100 fold excess unlabeled $\mathrm{HDL}_{3}(\mathrm{O})$ or in the presence of 100 -fold protein excess unlabeled LDL $(\Delta)$. Specific binding ( $\square$ ) was calculated by subtracting nonspecific $(0)$ from total binding $(\bullet)$ and was saturable. Excess unlabeled LDL partially inhibited ${ }^{125} \mathrm{I}-\mathrm{HDL}_{3}$ specific binding. Each point represents the average of duplicate assays. (B) Scatchard plot of ${ }^{125} \mathrm{I}-\mathrm{HDL}_{3}$ specific binding. Scatchard analysis was carried out as described in legend to Fig. 6. The molecular weight of $1.75 \times 10^{5}$ ( $55 \%$ protein) was used in the calculation.

contributed to a nondisplaceable portion of surface-bound HDL particles.

The role of apo $E$ in the binding of HDL to human adipocytes was explored using apo $\mathrm{E}$ poor normal $\mathrm{HDL}_{3}$, apo $E_{0}-H_{2}$, and apo $E_{0}-H_{2} L_{3}$ obtained from a patient with genetic apo $\mathrm{E}$ deficiency. All these apo $\mathrm{E}$ poor or deficient HDL particles bound specifically to human fat cells and to purified plasma membranes with similar affinity (Table VI). This suggests that the presence of apo $\mathrm{E}$ is not obligatory for $\mathrm{HDL}$ adipocyte interactions. Apo $\mathrm{E}_{0}-\mathrm{HDL}_{2}$, apo $\mathrm{E}_{0}-\mathrm{HDL}_{3}$, normal $\mathrm{HDL}_{2}$, and normal $\mathrm{HDL}_{3}$ binding were all partially inhibited by unlabeled LDL, which indicated that the crosscompetition between LDL and HDL particles is not dependent on an apo $E$ or apo B-E type of recognition $(22,48)$. This conclusion is further substantiated by our finding that abeta-

Table VI. $K_{d}$ and $B_{\max }$ of HDL Particles to Various Human Adipocyte Plasma Membrane Preparations

\begin{tabular}{|c|c|c|c|c|}
\hline $\begin{array}{l}\text { Experi- } \\
\text { ment }\end{array}$ & Membrane & HDL & $K_{\mathrm{d}}^{*}$ & $B_{\max }$ \\
\hline & & & $n M$ & $\mu g / m g$ \\
\hline 1 & M 67 yr & Normal $\mathrm{HDL}_{2}$ & 40 & 3.05 \\
\hline 2 & M 62 yr & Normal HDL & 96 & 7.68 \\
\hline 3 & M 65 yr & Normal $\mathrm{HDL}_{3}$ & 56 & 2.76 \\
\hline 4 & M 61 yr & Normal $\mathrm{HDL}_{3}$ & 69 & 2.15 \\
\hline 5 & F 59 yr & Apo $E_{0}-\mathrm{HDL}_{3}$ & 48 & 1.56 \\
\hline 6 & M $44 \mathrm{yr}$ & Apo $E_{0}-\mathrm{HDL}_{3}$ & 51 & 3.47 \\
\hline 7 & M $64 \mathrm{yr}$ & Apo $E_{0}-\mathrm{HDL}_{3}$ & 67 & 3.27 \\
\hline
\end{tabular}

Binding assays and methods of calculation for all the experiments were similar to that described in the legend to Fig. 6.

${ }^{*} K_{d}$ for experiments 1 and 4 correspond to values shown in Figs. 6 and 7 , respectively.
$\mathrm{HDL}_{3}$ and apo $\mathrm{E}_{0}-\mathrm{HDL}_{3}$ behaved similarly in completely inhibiting ${ }^{125} \mathrm{I}-\mathrm{LDL}$ binding to adipocyte membranes.

We conclude that HDL binding to human fat cells is probably related to apo A apoproteins. Indeed, studies on the effects of anti-apo AI and anti-apo AII antibodies on HDL binding suggest that both apo AI and apo AII, the major apoprotein components of HDL particles, may be involved in the binding of the lipoprotein particles to human adipocyte membranes (Fig. 5). While this is consistent with other cell types known to interact with HDL in a specific manner (14, 18,49 ), a role for other minor apoproteins (e.g., apo C's) and lipoprotein lipids in the binding process has not been excluded.

The cross-competition between LDL and HDL binding to adipocytes and purified membranes is substantial, and may be interpreted in a number of ways. The simplest interpretation is that $\mathrm{LDL}$ and HDL particles both bind to the same site. This could explain why $\mathrm{HDL}_{2}$ and $\mathrm{HDL}_{3}$ completely inhibit LDL binding, but fails to adequately explain the partial inhibition of $\mathrm{HDL}_{2}$ and $\mathrm{HDL}_{3}$ binding by LDL or the differential effect of high $\mathrm{NaCl}$ concentration on LDL and HDL specific binding. Another interpretation is that human adipocytes contain multiple lipoprotein binding sites consisting of one class that recognizes both LDL and HDL particles and another class that binds HDL particles only. Alternatively, the multiple sites may be constituted of distinct but juxtaposed LDL and HDL binding sites. The cross-competition of LDL and HDL binding may be accounted for in this case by steric hindrance or negative co-operativity. A third interpretation is that LDL and HDL bind to different conformations of the same binding domain. These different conformations may exhibit preferential interactions with LDL or HDL and may be differently affected by high $\mathrm{NaCl}$ concentration. This model may explain the relaxed binding specificity of human adipocytes for various lipoprotein particles and the latter's ability to modulate each other's binding.

We conclude from our present study that human adipose tissue, functioning through its lipoprotein binding sites or domain, is probably an important site of interaction for both low and high density lipoproteins in vivo. The lower than normal level of plasma HDL-cholesterol (50-53) and the increased rate of LDL turnover (54) observed in obesity might in fact be explained in part by an increase in lipoprotein metabolism by the expanded adipose mass in these individuals.

\section{Acknowledgments}

We thank Miss Erica Klazynski, Miss Lilly Lee, and Mrs. Laura Sheu for their excellent technical assistance. We are most grateful to Drs. B. Goldman, R. Baird, L. Mickleborough, H. Scully, and R. Weisel of the Division of Cardiac Surgery, Toronto General Hospital, for their support and interest in this work. We also thank Dr. W. Mak and Dr. D. Isenman for useful discussions and for their assistance in computer analysis of the Scatchard plots. We are indebted to Dr. R. Milne and Dr. Y. Marcel for providing the monoclonal antibodies.

This research was supported by the Medical Research Council of Canada and the Ontario Heart Foundation. Dr. Rodrigues is the recipient of a fellowship grant from the Ontario Heart Foundation.

\section{References}

1. Glomset, J. A. 1968. The plasma lecithin:cholesterol acyltransferase reaction. J. Lipid Res. 9:155-167. 
2. Tall, A. R., and D. M. Small. 1980. Body cholesterol removal: role of plasma high-density lipoproteins. Adv. Lipid Res. 7:1-51.

3. Andersen, J. M., and J. M. Dietschy. 1978. Relative importance of high and low density lipoproteins in the regulation of cholestero synthesis in adrenal gland, ovary, and testis of the rat. J. Biol. Chem. 253:9024-9032.

4. Tureck, R. W., and J. F. Strauss III. 1982. Progesterone synthesis by luteinized human granulosa cells in culture. The role of de novo sterol synthesis and lipoprotein carried sterol. J. Clin. Endocrinol. Metab. 54:367-373.

5. Azhar, S., and K. M. J. Menon. 1981. Receptor-mediated gonadotropin action in the ovary. J. Biol. Chem. 256:6548-6555.

6. Schuler, L. A., K. K. Langenberg, J. T. Gwynne, and J. F. Strauss III. 1981. High density lipoprotein utilization by dispersed rat luteal cells. Biochim. Biophys. Acta. 664:583-601.

7. Bruot, B. C., W. G. Wiest, and D. C. Collins. 1982. Effect of low density and high density lipoproteins on progesterone secretion by dispersed corpora luteal cells from rats treated with aminopyrazolo(3,4-d) pyrimidine. Endocrinology. 110:1572-1578.

8. Schreiber, J. R., A. J. W. Hsueh, D. B. Weinstein, and G. F. Erickson. 1980. Plasma lipoproteins stimulate progestin production by rat ovarian granulosa cells cultured in serum free medium. J. Steroid Biochem. 13:1009-1014.

9. Miller, N. E., D. S. Thelle, O. H. Forde, and O. D. Mjos. 1977. The Tromso Heart Study-High-density lipoprotein and coronary heart-disease: a prospective case-control study. Lancet. 8019:965-967.

10. Gordon, T., W. P. Castelli, M. C. Hjortland, W. B. Kannel, and T. R. Dawber. 1977. High-density lipoprotein as a protective factor against coronary heart disease: The Framingham Study. Am. J. Med. 62:707-730.

11. Kovanen, P. T., W. J. Schneider, G. M. Hillman, J. L. Goldstein, and M. S. Brown. 1979. Separate mechanisms for uptake of high and low density lipoproteins by mouse adrenal gland in vivo. J. Biol. Chem. 254:5498-5505.

12. Andersen, J. M., and J. M. Dietschy. 1981. Kinetic parameters of the lipoprotein transport systems in the adrenal gland of the rat determined in vivo. J. Biol. Chem. 256:7362-7370.

13. Chen, Y. I., F. B. Kraemer, and G. M. Reaven. 1980 Identification of specific high density lipoprotein-binding sites in rat testis and regulation of binding by human chorionic gonadotropin. $J$. Biol. Chem. 255:9162-9167.

14. Christie, M. H., J. T. Gwynne, and J. F. Strauss III. 1981 Binding of human HDL to membranes of luteinized rat ovaries. $J$ Steroid Biochem. 14:671-678.

15. Strauss, J. F., III, J. C. MacGregor, and J. T. Gwynne. 1982. Uptake of high density lipoproteins by rat ovaries in vivo and dispersed ovarian cells in vitro. Direct correlation of high density lipoprotein uptake with steroidogenic activity. J. Steroid Biochem. 16:525-531.

16. Nakai, T., P. S. Otto, D. L. Kennedy, and T. F. Whayne, Jr. 1976. Rat high density lipoprotein $\left(\mathrm{HDL}_{3}\right)$ uptake and catabolism by isolated rat liver parenchymal cells. J. Biol. Chem. 251:4914-4921.

17. O'Malley, J. P., P. A. Soltys, and O. W. Portman. 1981. Interaction of free cholesterol and apoproteins of low and high density lipoproteins with isolated rabbit hepatocytes. J. Lipid Res. 22:12141224.

18. Bachorik, P. S., F. A. Franklin, D. G. Virgil, and P. O. Kwiterovich, Jr. 1982. High affinity uptake and degradation of apolipoprotein $\mathrm{E}$ free high-density lipoprotein and low-density lipoprotein in cultured porcine hepatocytes. Biochemistry. 21:5675-5684.

19. Suzuki, N., N. Fidge, P. Nestel, and J. Yin. 1983. Interaction of serum lipoproteins with the intestine. Evidence for specific high density lipoprotein-binding sites on isolated rat intestinal mucosal cells. J. Lipid Res. 24:253-264.

20. Biesbroeck, R., J. F. Oram, J. J. Albers, and E. L. Bierman. 1983. Specific high-affinity binding of high density lipoproteins to cultured human skin fibroblasts and arterial smooth muscle cells. $J$. Clin. Invest. 71:525-539.

21. Glass, C. K., R. C. Pittman, G. A. Keller, and D. Steinberg.
1983. Tissue sites of degradation of apoprotein A-1 in the rat. J. Biol. Chem. 258:7161-7167.

22. Mahley, R. W., D. Y. Hui, T. L. Innerarity, and K. H. Weisgraber. 1981. Two lipoprotein receptors on hepatic membranes of dog, swine and man. J. Clin. Invest. 68:1197-1206.

23. Angel, A., M. A. D'Costa, and R. Yuen. 1979. Low density lipoprotein binding, internalization and degradation in human adipose cells. Can. J. Biochem. 57:578-587.

24. Schreibman, P. H., and R. B. Dell. 1975. Human adipocyte cholesterol-concentration, localization, synthesis, and turnover. $J$. Clin. Invest. 55:986-993.

25. Angel, A. 1973. Cholesterol and obesity. In Obesity in Perspective. Proceedings of the Fogarty Conference, Vol. 2. G. A. Bray, editor. DHEW publication, NIH No. 75-708. Wash. DC. 265-327.

26. Fong, B. S., P. O. Rodrigues, and A. Angel. 1984. Characterization of low-density lipoprotein binding to human adipocytes and adipocyte membranes. J. Biol. Chem. 259:10168-10174.

27. Havel, R. J., H. Eder, and H. F. Bragden. 1955. The distribution and chemical composition of ultracentrifugally separated lipoproteins in human serum. J. Clin. Invest. 34:1345-1353.

28. Ghiselli, G., E. J. Schaefer, P. Garcon, and H. B. Brewer, Jr. 1981. Type III hyperlipoproteinemia associated with apolipoprotein E deficiency. Science (Wash. DC). 214:1239-1241.

29. Hegele, R., and A. Angel. 1985. Arrest of neuropathy and myopathy in abetalipoproteinemia by high dose vitamin E. Can. Med. Assoc. J. 132:41-44.

30. Weber, K., and M. Osborn. 1969. The reliability of molecular weight determinations by dodecyl-sulfate-polyacrylamide gel electrophoresis. J. Biol. Chem. 244:4406-4412.

31. Shephard, J., D. K. Bedford, H. G. Morgan, and E. Scott. 1976. Radioiodination of human low density lipoprotein: a comparison of four methods. Clin. Chim. Acta. 66:97-109.

32. Weisgraber, K. H., T. L. Innerarity, and R. W. Mahley. 1978. Role of lysine residues of plasma lipoproteins in high affinity binding to cell surface receptors on human fibroblasts. J. Biol. Chem. 253: 9053-9062.

33. Mahley, R. W., T. L. Innerarity, P. E. Pitas, K. H. Weisgraber, J. H. Brown, and E. Gross. 1977. Inhibition of lipoprotein binding to cell surface receptors of fibroblasts following selective modification of arginyl residues in arginine-rich and B apoproteins. J. Biol. Chem. 252:7279-7287.

34. Rodbell, M. 1964. Metabolism of isolated fat cells. I. Effects of hormones on glucose metabolism and lipolysis. J. Biol. Chem. 239: 375-380.

35. McKeel, D. W., and L. Jarett. 1970. Preparation and characterization of a plasma membrane fraction from isolated fat cells. $J$. Cell. Biol. 44:417-432.

36. Avruch, J., and D. F. H. Wallach. 1971. Preparation and properties of plasma membrane and endoplasmic reticulum fragments from isolated rat fat cells. Biochim. Biophys. Acta. 233:334-347.

37. Pennington, R. J. 1961. Biochemistry of dystrophic musclemitochondrial succinate-tetrazolium reductase and adenosive triphosphatase. Biochem. J. 80:649-654.

38. Hunt, R. C., and D. J. Ellan. 1974. Isolation of the plasma membrane of a trypanosomatid flagellate: general characterization and lipid composition. Biochim. Biophys. Acta. 399:173-189.

39. Wallach, D. F. H., and V. B. Kamat. 1966. Preparation of plasma membrane fragments from mouse ascites carcinoma cells. In Methods in Enzymology, Vol. 8. S. P. Colowick and N. O. Kaplan, editors. Academic Press, Inc., New York. 164-172.

40. Basu, S. K., J. L. Goldstein, and M. S. Brown. 1978. Characterization of the low density lipoprotein receptor in membranes prepared from human fibroblasts. J. Biol. Chem. 253:3852-3856.

41. Scatchard, G. 1949. The attractions of proteins for small molecules and ions. Ann. NY. Acad. Sci. 51:660-672.

42. Marquardt, D. W. 1963. An algorithm for least-squares estimation of nonlinear parameters. J. Soc. Ind. Appl. Math. 11:431-441.

43. Weisgraber, K. H., T. L. Innerarity, K. J. Harder, R. W. 
Mahley, R. W. Milne, Y. L. Marcel, and J. T. Sparrow. 1983. The receptor-binding domain of human apolipoprotein E-monoclonal antibody inhibition of binding. J. Biol. Chem. 258:12348-12354.

44. Milne, R. W., R. Theslis, Jr., R. B. Verdeny, and Y. L. Marcel. 1983. Characterization of monoclonal antibodies against human low density lipoprotein. Arteriosclerosis. 3:23-30.

45. Cummings, S. W., W. Hatley, E. R. Simpson, and M. Ohasi. 1982. The binding of high and low density lipoproteins to human placental membrane fractions. J. Clin. Endocrinol. Metab. 54:903908.

46. Chen, Y. D. I., G. M. Reaven, C. Hollenbeck, and S. K. Erickson. 1984. Identification of high density lipoprotein (HDL) binding sites in human liver membranes. Clin. Res. 32(2):391A. (Abstr.)

47. Williamson, J. R., and P. E. Lacy. 1965. Structural aspects of adipose tissue: a summary attempting to synthesize the information contained in the preceding chapters. In Handbook of Physiology, Section 5: Adipose Tissue. A. E. Renold and G. F. Cahill, Jr., editors. American Physiological Society, Wash., DC. 201-210.

48. Hui, D. Y., T. L. Innerarity, and R. W. Mahley. 1981 Lipoprotein binding to canine hepatic membranes. Metabolically distinct apo-E and apo B,E receptors. J. Biol. Chem. 256:5646-5655.
49. Tauber, J. P., D. Goldminz, and D. Gospodarowicz. 1981. Upregulation in vascular endothelial cells of binding sites of high density lipoprotein induced by 25-hydroxycholesterol. Eur. J. Biochem. 119: 327-339.

50. Sutherland, W. H. F., W. A. Temple, E. R. Nye, and G. P. Herbison. 1980. Adiposity, lipids, alcohol consumption, smoking and gender. Am. J. Clin. Nutr. 21:417-433.

51. Glueck, C. J., H. L. Taylor, D. Jacobs, J. A. Morrison, R. Beaglehole, and O. D. Williams. 1980. Plasma high-density lipoprotein cholesterol. Associations with measurements of body mass. The Lipid Research Clinics Program Prevalence Study. Circulation. 62(Suppl IV): 62-69.

52. Albrink, M. J., R. M. Krauss, F. T. Lindgren, J. von der Graeben, S. Pan, and P. D. Wood. 1980. Intercorrelations among plasma high density lipoproteins, obesity and triglycerides in a normal population. Lipids. 14:668-676.

53. Avogardo, P., G. Cazzolato, G. Bittolobon, G. B. Quinci, and M. Chinello. 1978. HDL cholesterol, apolipoproteins A, and B. Age and index body weight. Atherosclerosis. 31:85-91.

54. Kesaniemi, Y. A., and S. M. Grundy. 1983. Increased low density lipoprotein production associated with obesity. Arteriosclerosis. 3:170-177. 